\title{
KELIMPAHAN KERANG DARAH (Genus: Anadara) di PERAIRAN PANTAI LABUHAN TERENG KABUPATEN LOMBOK BARAT
}

\author{
Meyla Fitri Handayani* ${ }^{* 1}$, Muhlis ${ }^{2}$, Erin Ryantin Gunawan ${ }^{3}$ \\ ${ }^{1}$ Magister Pendidikan IPA Program Pasca Sarjana Universitas Mataram \\ ${ }^{2}$ Program Studi Pendidikan Biologi, FKIP, Universitas Mataram \\ ${ }^{3}$ Program Studi Kimia, Fakultas MIPA, Universitas Mataram \\ *Email: meylafitrihandayani@gmail.com
}

\begin{abstract}
Abstrak: Penelitian ini bertujuan untuk menganalisis kelimpahan kerang darah (Genus: Anadara) di perairan pantai Labuhan Tereng Kabupaten Lombok Barat. Penelitian menggunakan metode acak sistematik dengan cara membentangkan 5 transek garis tegak lurus kearah pantai. Masing-masing transek terdiri atas 3 plot dengan ukuran $5 \times 5 \mathrm{~m}^{2}$. Hasil pengamatan menunjukkan bahwa terdapat total 11 jenis kerang dan 3 diantaranya termasuk dalam genus Anadara yaitu Anadara granosa, Anadara antiquata, dan Anadara cornea. Kelimpahan kerang darah tertinggi terdapat pada spesies A. cornea yaitu $2.08 \mathrm{Ind} / \mathrm{m}^{2}$ di pesisir seberang Kampong Punyahan, dan yang terendah terdapat pada spesies A. granosa dan A. antiquata yaitu $0.04 \mathrm{Ind} / \mathrm{m}^{2} \mathrm{di}$ pesisir Dusun Cemara dan dan di sekitar muara Kebon Talo.
\end{abstract}

Kata Kunci: Anadara, Kelimpahan, kerang

\begin{abstract}
The aim of this research is to analyze the abundance of blood cockle (Genus: Anadara) in Labuhan Tereng Coastal Waters West Lombok. Research methodology was randomized systematic with unfluring 5 transects toward the beach. Each transect consisted of three plots with $5 \times 5 \mathrm{~m}^{2}$. The research showed that there are 11 species in which tree species was representing genus anadara: Anadara granosa, Anadara cornea, and Anadara antiquata. The highest abundance of blood cockle is $2.08 \mathrm{Ind} / \mathrm{m}^{2}$ on the species A. cornea which located across from Punyahan village and the lower abundance of blood cockle is $0.04 \mathrm{Ind} / \mathrm{m}^{2}$ on the species A. granosa and A. antiquata around Dusun Cemara and Kebon Talo estuary.
\end{abstract}

Keywords: Anadara, Abundance, cockle.

\section{PENDAHULUAN}

Aktifitas Perairan di Pesisir Pantai Labuhan Tereng Kabupaten Lombok Barat merupakan wilayah yang memiliki potensi, baik sumberdaya perairan maupun pesisir yang dimanfaatkan sebagai aktifitas dan jasa-jasa lingkungan yang meliputi pemungkiman, aktifitas nelayan, dan kegiatan Pelabuhan Lembar. Berbagai aktivitas di sekitar Perairan Pantai Labuhan Tereng Kabupaten Lombok Barat tersebut dapat menghasilkan dampak yang berpengaruh terhadap lingkungan perairan. Limbah yang berasal dari daratan akan terbawa melalui sungai dan masuk kedalam lautan. Salah satu limbah yang sangat berbahaya bagi biota laut dan manusia yang mengkonsumsinya adalah limbah logam berat $\mathrm{Pb}$.

Logam berat $\mathrm{Pb}$ masuk ke lingkungan laut kebanyakan terjadi akibat adanya buangan limbah industri yang masuk melalui tiga cara yaitu: pembuangan limbah industri yang tidak dikontrol, lumpur minyak yang juga mengandung logam berat dengan konsentrasi tinggi, serta adanya pembakaran minyak hidrokarbon dan batubara di daratan [13]. Salah satu logam berat yang bersifat toksik dan dapat mencemari lingkungan perairan yaitu $(\mathrm{Pb})$. Namun, banyak penelitian yang menyatakan bahwa masuknya logam berat $\mathrm{Pb}$ ke perairan disebabkan oleh aktifitas perkapalan.
Diperkuat oleh penelitian [1], [17], dan [8] yang menyatakan bahwa sumber pencemar $\mathrm{Pb}$ masuk keperairan diperkirakan kebanyakan berasal dari aktivitas kapal-kapal nelayan, kapal-kapal penyebrangan dan bahan pencemar yang terbawa oleh arus. Hasil penelitian [18] juga menyatakan bahwa Tingginya konsentrasi logam $\mathrm{Pb}$ di danau salah satunya dapat berasal dari kegiatan buangan sisa bahan bakar kapal motor, cat kapal, dan kegiatan wisata. Hasil Penelitian [20], juga menyatakan bahwa sumber bahan pencemar $\mathrm{Pb}$ dapat berasal dari limbah minyak dari kapal.

Pelabuhan lembar merupakan salah satu pelabuhan terbesar di Lombok dan berlokasi di pantai Labuhan Tereng [7]. Aktifitas perkapalan yang terjadi di kawasan pantai labuhan tereng dapat menyebabkan masuknya logam berat seperti Timbal kedalam badan perairan dan dapat mengganggu kehidupan biota laut salah satunya kehidupan kerang. Bivalvia adalah moluska yang secara tipikal mempunyai dua katup, dan kedua bagiannya lebih kurang simetris. Kerangkanya disusun oleh kalsifikasi katup yang ada di sisi kanan dan kiri tubuh. Katupnya dikatupkan di sepanjang tepi dorsal yang disebut hinge, dan dihubungkan oleh stuktur kapur yang elastis yang disebut ligamen. Mereka ditutup dengan aksi menarik satu atau dua (kadang tiga) otot aduktor. 
Byssus atau kaki menonjol keluar dari anterior kerangkanya, dimana posterior dari kerangkanya adalah dimana ada tonjolan siphon. Kebanyakan kerang adalah filter feeder, tetapi ada beberapa yang scavenger (pemakan bangkai) atau bahkan predator. Di dunia, ada 10.0000 spesies kerang [12].

[10] menyatakan bahwa logam berat dapat terkonsentrasi melalui rantai makanan dan terakumulasi dalam organisme yang bersifat benthic seperti pada jenis bivalvia. Kelompok bivalva diketahui dapat mengakumulasikan jenisjenis polutan sampai pada jumlah yang membahayakan bagi konsumen. Hal ini berhubungan erat dengan sifat filter feeder yang dimilikinya dan cara hidupnya yang relatif menetap, sehingga kecil kemungkinannya untuk menghindar dari perubahan lingkungan perairan yang membahayakan.

Berdasarkan hasil penelitian [19] yang menyatakan bahwa kerang darah dapat dijadikan bioindikator karena kemampuan mengakumulasi yang direpresentasikan oleh nilai factor bioakumulasi konsentrasi maksimal sebesar 835,75 kali dibandingkan kosentrasinya dalam air laut dan kejadian polusi dapat terdeteksi walaupun hanya berlangsung 1 hari. Menurut [16], Bila akumulasi logam berat semakin meningkat seiring dengan waktu dan peningkatan konsentrasi logam berat ke perairan, maka kerang diduga akan mengalami gangguan dalam melakukan filtrasi makanan, sehingga kerang akan mengalami penurunan dalam pertumbuhan dan bahkan dimungkinkan mengalami kematian. Sehingga gangguan yang disebabkan oleh logam berat $\mathrm{Pb}$ pada kerang secara tidak langung dapat ditinjau dari kelimpahan kerang yang ada di Perairan Pantai Labuhan Tereng Kabupaten Lombok Barat.

\section{METODE PENELITIAN}

Penelitian ini dilakukan selama bulan JuliSeptember 2015 dengan tiga kali pengambilan sampel di Perairan Labuhan Tereng Kabupaten Lombok Barat.

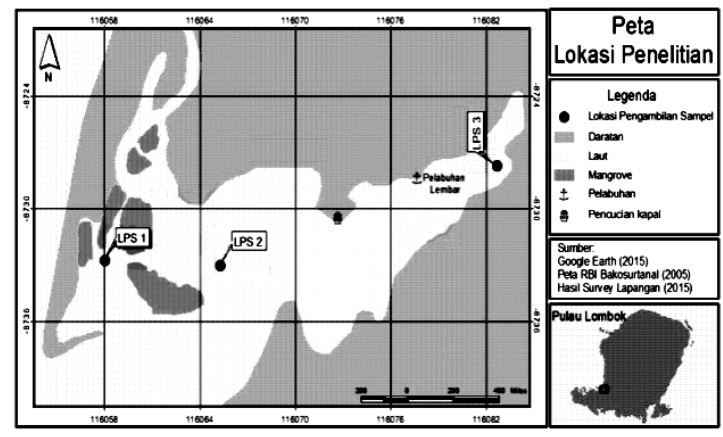

Gambar 1. Peta Lokasi penelitian Kelimpahan kerang darah (Genus: Anadara) di perairan Pantai Labuhan Tereng Kabupaten Lombok Barat.

\section{Pengambilan sampel bivalvia}

Penelitian ini dilakukan di tiga stasiun pengamatan pada Pesisir Labuhan Tereng (gambar 1) yang meliputi LPS-I (844'3.01"S-116 3'28.73"E), LPSII $\left(8^{\circ} 44^{\prime} 0.24^{\prime \prime S}-116^{\circ} 3^{\prime} 54.98^{\prime \prime E}\right)$, dan LPS-III ( $\left.8^{\circ} 43^{\prime} 51.58^{\prime \prime S}-116^{\circ} 4^{\prime} 50.91 " \mathrm{E}\right)$. Masing-masing stasiun pengamatan diukur parameter fisika (Kedalaman air ketika surut, kedalaman air ketika pasang, suhu, dan fraksi sedimen) dan kimianya $(\mathrm{pH}$, salinitas, kadar $\mathrm{Pb}$ pada sedimen, dan kadar $\mathrm{Pb}$ pada kerang darah).

Metode pengambilan sampel yang digunakan adalah metode acak sistematik (Gambar 2) dengan cara membentangkan 5 transek garis tegak lurus ke arah pantai dengan jarak masing-masing transek garis yaitu $20 \mathrm{~m}$ pada setiap sub stasiun pengamatan. Pada setiap sub stasiun

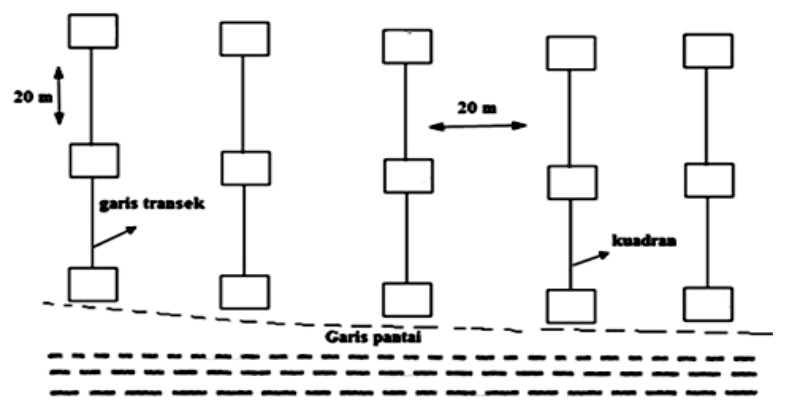

Gambar 2. Desain pengambilan sampel kerang pada setiap sub stasiun pengamatan

pengamatan dibagi menjadi 3 plot $(5 \mathrm{mx} 5 \mathrm{~m})$ sehingga jumlah plot yang diamati pada setiap sub stasiun pengamatan berjumlah 15 plot.

\section{Analisis Data}

[11] mengatakan bahwa kelimpahan organisme dalam suatu perairan dapat dinyatakan sebagai jumlah individu persatuan luas dan volume. Kelimpahan dapat dihitung dengan menggunakan rumus sebagai berikut:

$$
\mathrm{A}=\frac{X i}{N i}
$$

Dimana:
A : Kelimpahan
$\mathrm{Xi}$ : Jumlah individu dari spesies ke- $\mathrm{i}$
$\mathrm{Ni}$ : Luasan kuadran jenis ke-i ditemukan $\left(\mathrm{m}^{2}\right)$

\section{HASIL DAN PEMBAHASAN}

Terdapat sebelas jenis kerang yang mewakili tiga lokasi pengambilan sampel di pesisir pantai Labuhan Tereng Kabupaten Lombok Barat, tiga diantaranya berasal dari genus Anadara. 10 jenis 
kerang terdapat pada LPS-II, 7 jenis terdapat pada LPS-I, dan 6 jenis terdapat pada LPS-III. Perbedaan kelimpahan jenis pada masing-masing stasiun ini dapat disebabkan oleh variasi parameter fisika, kimia, biologi perairan (Tabel 1).

Tabel 1. Hasil pengukuran parameter fisika-kimia perairan pada tiap stasiun pengamatan.

\begin{tabular}{|c|c|c|c|c|c|c|c|c|c|c|}
\hline \multirow{3}{*}{ No } & \multirow{3}{*}{ Parameter } & \multicolumn{3}{|c|}{ Stasiun 1} & \multicolumn{3}{|c|}{ Stasiun 2} & \multicolumn{3}{|c|}{ Stasiun 3} \\
\hline & & \multicolumn{3}{|c|}{ Pengambilan ke- } & \multicolumn{3}{|c|}{ Pengambilan ke- } & \multicolumn{3}{|c|}{ Pengambilan ke- } \\
\hline & & I & II & III & I & II & III & I & II & III \\
\hline 1. & $\begin{array}{l}\text { Kedalaman } \\
\text { perairan ketika } \\
\text { surut }(\mathrm{cm})\end{array}$ & $0-33$ & $0-3$ & $0-7$ & $0-48$ & $0-4$ & $0-8$ & $0-12$ & $0-3$ & $0-9$ \\
\hline 2. & $\begin{array}{l}\text { Kedalaman } \\
\text { perairan ketika } \\
\text { Pasang }(\mathrm{cm})\end{array}$ & $30-126$ & $32-122$ & $36-119$ & $45-153$ & $53-151$ & 53-158 & $34-78$ & $36-86$ & $34-71$ \\
\hline 3. & Suhu $\left({ }^{\circ} \mathrm{C}\right)$ & 32 & 31 & 33 & 30 & 32 & 31 & 28 & 30 & 29 \\
\hline 4. & $\begin{array}{l}\text { Fraksi sedimen } \\
(\%)\end{array}$ & $\begin{array}{ll}\text { - } & \text { Pasir } \\
\text { - } & \text { Debu } \\
\text { - } & \text { Liat } \\
\end{array}$ & $\begin{array}{l}: 80 \% \\
: 16.67 \% \\
: 3.33 \% \\
\end{array}$ & & $\begin{array}{ll}\text { - } & \text { Pasir } \\
\text { - } & \text { Debu } \\
\text { - } & \text { Liat } \\
\end{array}$ & $\begin{array}{l}: 73.33 \% \\
: 23.34 \% \\
: 3.33 \% \\
\end{array}$ & & $\begin{array}{l}\text { - } \mathrm{Pa} \\
\text { - } \mathrm{De} \\
\text { - } \mathrm{Li} \\
\end{array}$ & $\begin{array}{l}: 6.67 \\
: 20 \% \\
: 73.33 \\
\end{array}$ & \\
\hline \multicolumn{11}{|c|}{ Kimia } \\
\hline 1. & $\mathrm{Ph}$ & 8 & 8 & 8 & 8 & 8 & 8 & 8 & 8 & 8 \\
\hline 2. & $\begin{array}{l}\text { Salinitas } \\
\text { (ppm) }\end{array}$ & 31.04 & 32.35 & 32.05 & 32.57 & 34.23 & 32.98 & 30.9 & 29.53 & 30.04 \\
\hline
\end{tabular}

Kelimpahan rata-rata \pm SD tertinggi $(3.05$ $\mathrm{Ind} / \mathrm{m}^{2} \pm 5.12$ ) terdapat pada LPS-I dan LPS-II (2.74 Ind $\left./ \mathrm{m}^{2} \pm 4.25\right)$, sedangkan kelimpahan ratarata \pm SD terendah $\left(2.41 \mathrm{Ind} / \mathrm{m}^{2} \pm 4.65\right)$ terdapat pada LPS-III (Gambar 3). Standar deviasi atau sering disebut simpangan baku, mengambarkan seberapa besar perbedaan nilai sampel terhadap rata-ratanya. Semakin besar nilai standar deviasi maka data sampel semakin menyebar (bervariasi) dari rataratanya. Sebaliknya jika semakin kecil maka data sampel semakin homogen (hampir sama).

Tingginya kelimpahan rata-rata pada LPS-I dan LPS-II dapat disebabkan oleh kondisi fisika, kimia, dan biologi perairan yang mendukung pertumbuhan bivalvia. Selain itu, hal yang dapat mendukung pertumbuhan kerang pada stasiun ini juga dikarenakan banyaknya lamun yang hidup disekitar LPS-I dan LPS-II. Secara ekologis, perairan di wilayah padang lamun memiliki beberapa fungsi penting di perairan pantai. Fungsi lamun diantaranya adalah sebagai penyedia tempat berlindung bagi organisme-organisme laut yang hidup di dalamnya. Menurut [5], Padang lamun merupakan daerah asuhan ('nursery ground') bagi beberapa spesies biota laut seperti kelompok krustacea, polychaeta, echinodermata, bivalvia (kerang-kerangan), gastropoda dan kelompok ikanikan baik juvenil maupun dewasa.

Tapes sp. merupakan spesies dengan kelimpahan tertinggi pada LPS-I dan LPS-II, sedangkan pada LPS-III kelimpahan kerang ini sangat rendah (Gambar 3). Hal ini diakibatkan oleh perbedaan tipe substrat diantara ketiga lokasi pengambilan sampel. LPS-I dan LPS-II memiliki struktur substrat dengan kandungan pasir lebih tinggi, sedangkan LPS-III memiliki struktur substrat dengan kandungan lumpur lebih tinggi. Menurut [4], spesies Tapes sp. hidup pada substrat dasar berpasir, dan kebanyakan ditemukan pada pasir halus dan pasir berlumpur didekat mangrove pada daerah tidal serta dataran dangkal intertidal.

Secara keseluruhan kerang darah di pesisir pantai Labuhan Tereng memiliki kelimpahan yang relatif rendah. Pada LPS-I terdapat tiga jenis kerang darah, A. granosa dengan keimpahan 0.04 $\mathrm{Ind} / \mathrm{m}^{2}$, A. antiquata dengan kelimpahan 0.16 $\mathrm{Ind} / \mathrm{m}^{2}$ dan A. cornea dengan kelimpahan 0.36 $\mathrm{Ind} / \mathrm{m}^{2}$. pada LPS-II A. antiquata memiliki kelimpahan $1.12 \mathrm{Ind} / \mathrm{m}^{2}$ dan A. cornea 2.08 $\mathrm{Ind} / \mathrm{m}^{2}$. kelimpahan kerang darah terendah terdapat pada LPS-III, yaitu $0.08 \mathrm{Ind} / \mathrm{m}^{2}$ untuk A. cornea dan $0.04 \mathrm{Ind} / \mathrm{m}^{2}$ untuk A. antiquata.

Anadara antiquata terdapat pada ketiga stasiun pengamatan dengan kelimpahan tertinggi terdapat pada LPS-II, dan yang terendah pada LPS III. Berdasarkan hasil penelitian [9], rendahnya kepadatan populasi kerang A. antiquata dapat disebabkan oleh toleransi kerang A. antiquata yang kurang terhadap salinitas dan substrat dasar, serta lokasi dekat hutan mangrove dengan salinitas yang rendah dan substrat yang sangat halus serta berlumpur. Kerang A. antiquata habitatnya perairan laut pada daerah sublitoral dan substrat pasir berlumpur. Sehingga rendahnya kelimpahan A. antiquata pada LPS-III dibandingkan kedua stasiun lainnya dapat disebabkan karna lokasi pengambilan sampel yang dekat dengan muara sungai dan lokasi area pengambilan sampel yang terletak dekat dengan kawasan mangrove. Rendahnya kelimpahan A. antiquata juga dapat disebabkan oleh salinitas LPS-III yg relatif lebih rendah dibandingkan lokasi pengambilan sampel 
lainnya (Gambar 1) karna terletak dengan muara Kebon Talo. Menurut [6], ketika arus pasut sedang surut, maka aliran sungai mengarah kearah laut dan bersalinitas rendah sekali (freshwater) sehingga menyebabkan salinitas lebih rendah.

Anadara cornea hanya terdapat pada LPS-II dan LPS-I, dan tidak terdapat pada LPS-III. Kelimpahan A. cornea pada LPS-II lebih tinggi jika dibandingkan spesies Anadara lainnya. Hal ini berkaitan dengan tipe substrat yang merupakan habitat dari A. cornea. Hasil penelitian [3] yang menyatakan bahwa A. subcrenata/ A. cornea hidup pada substrat pasir berlumpur (50-80\% pasir). Sehingga A. cornea tidak ditemukan pada LPS-III disebabkan oleh substrat stasiun pengamatan ini yang dominan oleh lumpur (Tabel 1).

Kerang darah yang ditemukan disekitar Pesisir Perairan Pantai Labuhan Tereng Kabupaten Lombok Barat memiliki ukuran cangkang yang bervariasi. Namun, secara keseluruhan kerang yang berukuran kecil $(<3 \mathrm{~cm})$ lebih banyak ditemukan didalam kawasan sampel area dibandingkan kerang yang berukuran lebih besar $(>3 \mathrm{~cm})$.

Beberapa hal yang dapat menyebabkan melimpahnya kerang darah khususnya A. cornea dan A. antiquata berukuran kecil pada kawasan sampel area yaitu: Kedalaman Perairan. Kerang yang berukuran besar pada kedua jenis kerang darah cenderung hidup pada tempat yang lebih dalam, sedangkan yang berukuran kecil hidup pada perairan yang tenang disekitar pesisir pantai. Berdasarkan hasil wawancara kepada para nelayan, menyatakan bahwa kerang bulu (A. antiquata) yang berukuran besar biasanya mereka dapatkan di daerah yang lebih dalam. Mereka biasanya mencari dengan menggunakan kerang dengan menggunakan kaki ataupun serokan. Hal ini sesuai dengan pendapat [9], yang menyatakan bahwa penyebaran kerang A. antiquata berukuran lebih besar (di atas $30 \mathrm{~mm})$
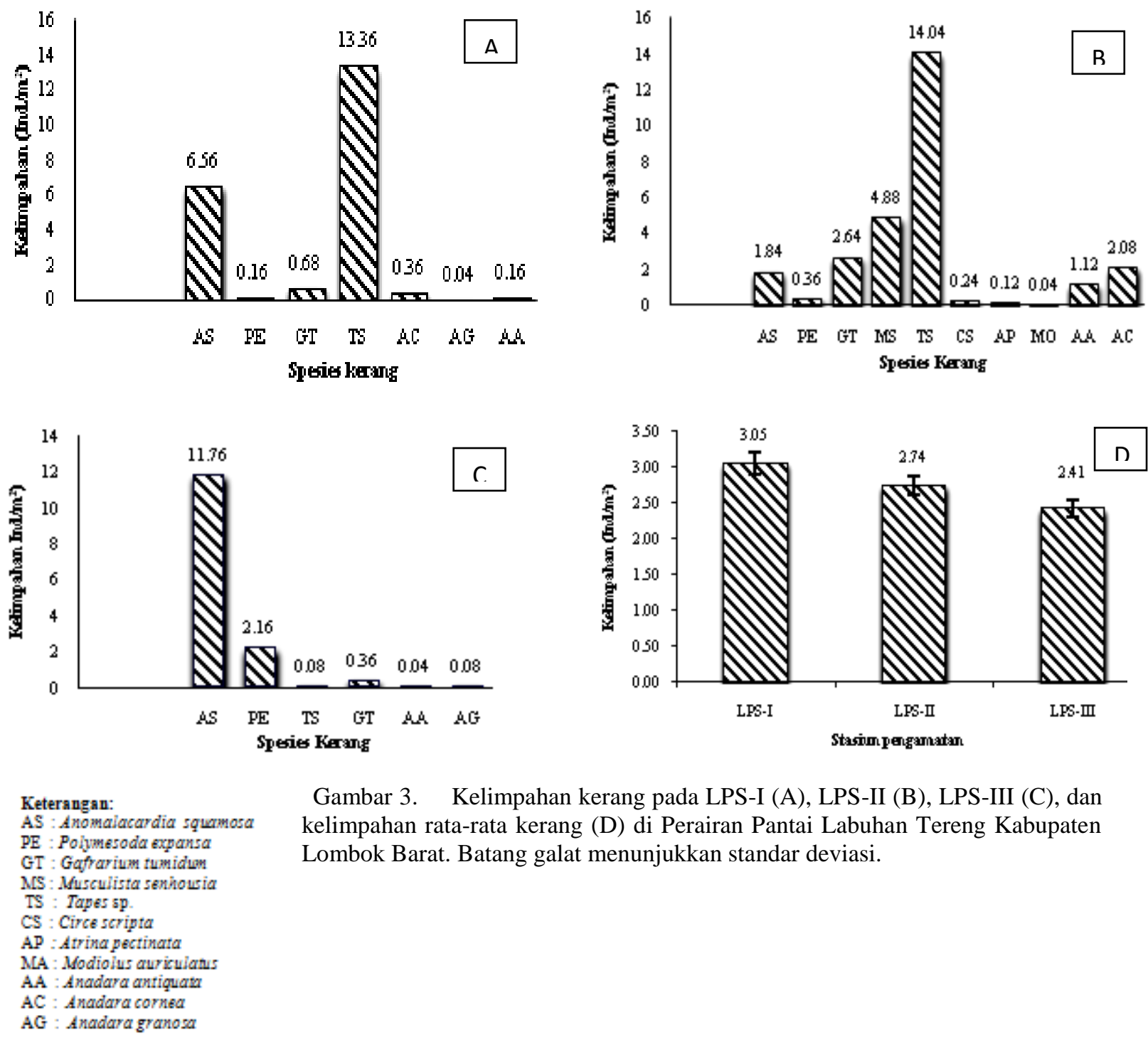

Gambar 3. Kelimpahan kerang pada LPS-I (A), LPS-II (B), LPS-III (C), dan kelimpahan rata-rata kerang (D) di Perairan Pantai Labuhan Tereng Kabupaten Lombok Barat. Batang galat menunjukkan standar deviasi. 
umumnya banyak ditemukan pada kedalaman 1-1,5 meter dan yang berukuran lebih kecil umumya ditemukan pada tepi pantai atau lokasi hempasan ombak.

2. Lokasi penangkapan kerang oleh nelayan. Nelayan lebih banyak mencari kerang pada daerah pesisir ketika air laut sedang surut.

3. Pola penangkapan kerang oleh nelayan. Dalam menangkap kerang, nelayan mengambil kerang yang berukuran besar, sedangkan kerang yang berukuran kecil akan dilepas kembali ke perairan agar tumbuh besar terlebih dahulu karna dianggap belum layak untuk dijual.

A. granosa merupakan spesies kerang darah yang hidup pada daerah yang dominan lumpur, dekat dengan kawasan mangrove dan disekitar muara sungai, sehingga LPS-III merupakan tempat yang sangat menunjang bagi perkembangan kehidupan A. granosa. Namun A. granosa yang ditemukan di LPS-III hanya satu ekor/ keseluruhan luas area sampling. Dibandingkan dengan LPS-I, LPS-III memiliki kandungan $\mathrm{Pb}$ pada sedimen lebih rendah (Gambar 4) namun kadar $\mathrm{Pb}$ pada kerang darah pada LPS-III lebih tinggi (Gambar 5).

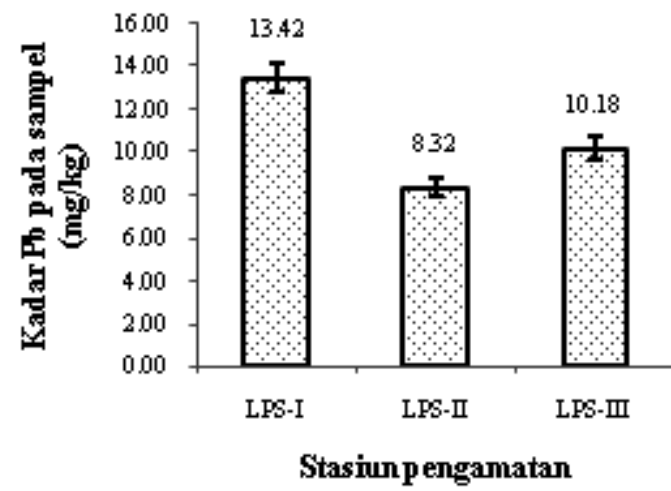

Gambar 4. Kandungan $\mathrm{Pb}$ sedimen pada masingmasing stasiun pengambilan sampel

Rendahnya kelimpahan A. granosa pada LPS-III ini dapat disebabkan oleh logam berat $\mathrm{Pb}$ yang berada pada sedimen dimana kerang hidup. Tipe sedimen lempung berpasir menyebabkan tingkat akumulasi kerang jauh lebih besar dibandingkan dengan tipe sedimen yang kandungan pasirnya lebih banyak seperti pada dua stasiun lainnya. Didukung oleh hasil penelitian [14], yang menyatakan walaupun kadar logam berat pada sedimen memiliki kadar lebih rendah, namun tingkat akumulasi logam berat oleh kerang darah lebih tinggi. Hal ini berkaitan erat dengan struktur sedimen. Didukung oleh pernyataan [2], bahwa sedimen dengan kandungan lumpur (debu) yang tinggi akan meningkatkan bioakumulasi logam berat.

Berdasarkan hasil penelitian, secara keseluruhan diantara ketiga lokasi pengambilan sampel kelimpahan kerang darah terendah terdapat pada LPS-III, yang berjarak lebih dekat dengan pelabuhan. Lokasi ini sangat jarang diganggu oleh para nelayan karna struktur sedimennya yang sangat berlumpur, sehingga rendahnya kelimpahan kerang darah tidak dapat dikaitkan dengan tangkapan para nelayan. Di sekitar area sampling LPS-III banyak terdapat tumpukan sampah serta cangkang kerang darah (kerang mati). Banyaknya kerang mati pada LPS-III ini dapat disebabkan tumpukan sampah yang dapat mengganggu kehidupan kerang dan kandungan logam berat pada sedimen. Berdasarkan hasil penelitian [15], disimpulkan bahwa kerang dapat mengakumulasi logam berat yang terdapat dalam linkungannya melalui makanan dan filtrasi. Hal ini terbukti dengan semakin menurunnya kemampuan filtrasi dan meningkatnya kandungan $\mathrm{Pb}$ dalam tubuh kerang darah. Bila akumulasi logam berat tersebut semakin meningkat seiring dengan waktu dan konsentrasi logam berat yang masuk ke perairan semakin bertambah, maka kerang darah diduga akan mengalami gangguan dalam melakukan filtrasi makanan, sehingga kerang tersebut akan mengalami penurunan dalam pertumbuhan dan bahkan dimungkinkan mengalami kematian. 


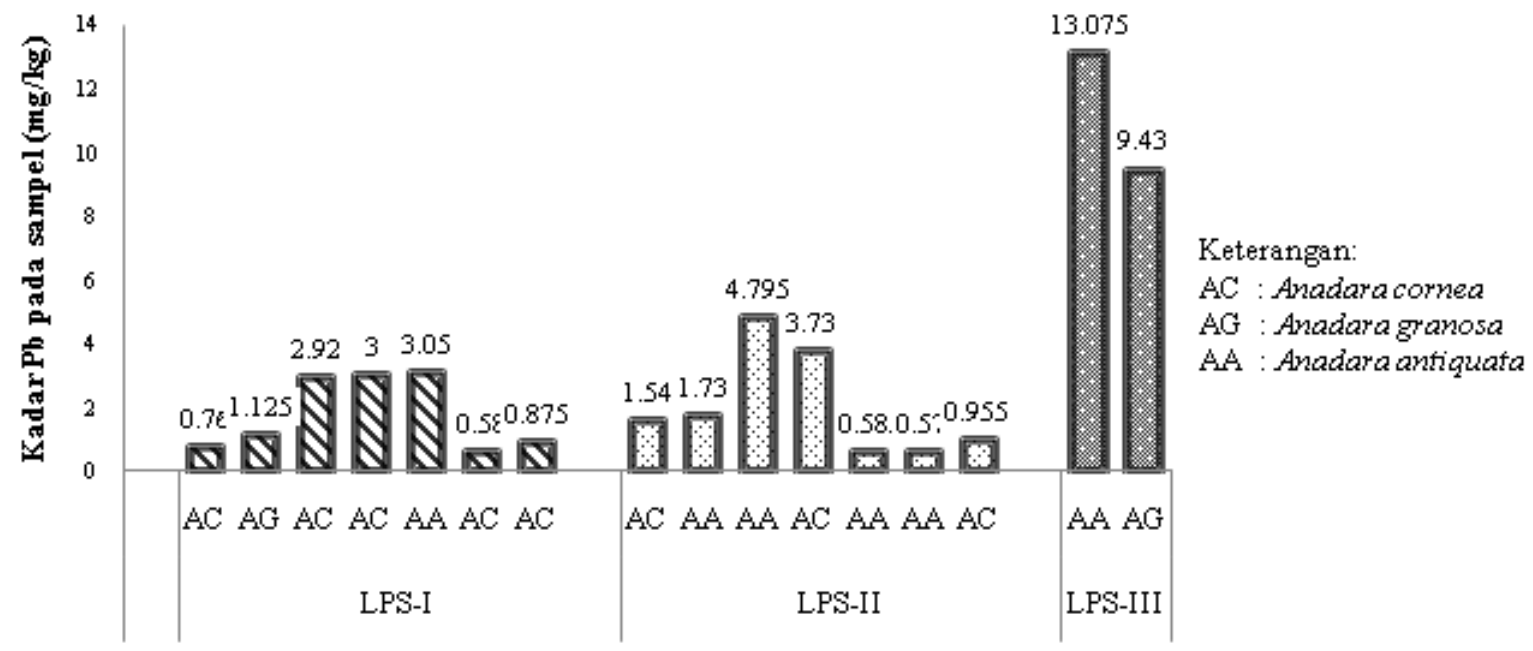

Spesies kerang darah

\section{KESIMPULAN}

Secara keseluruhan jenis kerang yang memiliki kelimpahan tertinggi di perairan pantai Labuhan Tereng Kabupaten Lombok Barat yaitu Tapes sp. Kelimpahan kerang darah tertinggi terdapat pada spesies A. cornea $\left(2.08 \mathrm{Ind} / \mathrm{m}^{2}\right)$ pada LPS-II dan kelimpahan kerang darah terendah pada spesies A. antiquata $\left(0.04 \mathrm{Ind} / \mathrm{m}^{2}\right)$ di LPS-III dan A. granosa (0.04 Ind $\left./ \mathrm{m}^{2}\right)$ di LPS-I. Rendahnya kelimpahan kerang darah di Perairan Pantai Labuhan tereng Kabupaten Lombok Barat dapat disebabkan oleh kondisi fisika-kimia perairan dan penangkapan yang dilakukan oleh nelayan setempat.

\section{DAFTAR PUSTAKA}

[1] Amin, B., Evy, A., dan Mikel, A.S. 2011. Distribusi Spasial Logam $\mathrm{Pb}$ Dan $\mathrm{Cu}$ Pada Sedimen Dan Air Laut Permukaan Di Perairan Tanjung Buton Kabupaten Siak Provinsi Riau. Teknobiologi II: 1-8.

[2] Amriani, Boedi, H., dan Agus H. 2011. Bioakumulasi Logam Berat $(\mathrm{Pb})$ dan Seng (Zn) Pada Kerang Darah (Anadara granosa L.) dan Kerang Bakau (Polymesoda begalensis L.) Di Perairan teluk Kendari. Ilmu Lingkungan 9: 45-50.

[3] Broom, M.J. 1985. The Biology and Culture of Marine Bivalve Molluscs of the Genus Anadara. ICLARM.

[4] Carpenter, K.E. \& Niem, V.H. 1998. The Living Marine of The Western Central Pacific Vol 1. Rome: FAO.

[5] Colles, R.G., Warren, J.L.L., Reg, T.W., and Kurt, J.P. 1993. Distribution of
Seagrasses, and Their Fish and Penaeid Prawn Communities, in Cairns Harbour, a Tropical Estuary, Northern Queensland, Australia. Aus. J. Mar. Freshwatter Res, 44: 193-210.

[6] Hadikusumah. 2008. Variabilitas Suhu dan Salinitas di Perairan Cisadane. Makara Sains Vol.12 No.2: 82-88

[7] Karyawan, I. 2012. Analisis Waktu Baku Pelayanan Kapal Di Pelabuhan Penyeberangan Lembar. Teknik Rekayasa 13: 1-12.

[8] Lubis, H. dan Challkuddin, A. 2008. Pemeriksaan Kandungan Logam Merkuri, dan Kadmium dalam Daging Rajungan Segar yang Berasal dari TPI Gabion Belawan Secara Spektrofotometri serapan Atom. Kedokteran Nusantara 41: 39-47.

[9] Nurdin, J., Neti, M., Izmiarti, Anjas. M., Rio, D., Jufri, M. 2006. Kepadatan Populasi dan Pertumbuhan Kerang Darah Anadara atiquata L. (Bivalvia: Arcidae) di Teluk Sungai Pisang, Kota Padang, Sumatra Barat. Makara, Sains 10: $96-101$

[10] Nurjannah, Hartanti, R.R., dan Nitibaskara. 1999. Analisa Kandungan Logam Berat $\mathrm{Hg}, \mathrm{Cd}, \mathrm{Pb}$, As dan $\mathrm{Cu}$ Dalam Tubuh Kerang Konsumsi. Buletin THP 1: 5-8.

[11] Odum, E.P. 1993. Dasar-Dasar Ekologi. Samingan, $T$ dan $B$. Srigandono (penerjemah). Gajah Mada University Press. Yogyakarta. 